\title{
OLHARES DA RECEPCÃO, A CRÍTICA CINEMATOGRÁFICA EM DOIS TEMPOS
}

\author{
Eliska Altmann*
}

\begin{abstract}
Com base em proposições da teoria da recepção, no campo da sociologia da cultura, o artigo discute o papel da crítica cinematográfica a partir de duas posições: a que defende o "cinema de autor" e a que se enquadra em um suposto "fim" da função crítica. O persistente debate a opor cinema (requintado) de arte ou de autor ao (fácil) industrial e massivo parece tão antigo quanto o próprio cinema e acaba por reduzi-lo à mera oposição “arte versus indústria”. Essa, por sua vez, parece ainda hoje um argumento medular no campo da crítica. A complexificação do pensar cinematográfico e artístico implica um deslocamento de sua recepção e, por conseguinte, de sua sociologia. Nesse sentido, pretende-se debater as possíveis relocalizações de conceitos, como os que circunscrevem o cinema em termos de "alto" versus "baixo" e "educado" versus "vulgar".

PALAVRAS-CHAVE: crítica cinematográfica, sociologia da cultura, teoria da recepção.
\end{abstract}

Interioridade versus exterioridade, indivíduo-artista versus coletividade, dom inato versus aprendizado cultural. Esses possíveis opostos, que compõem o domínio da arte, podem ser vistos como afirmativos de certos valores sobre os quais é constituída a sociologia. Ao pensar sociologicamente a arte, o pesquisador pode encontrar dois importantes caminhos metodológicos: 1) percebêla como fenômeno coletivo, habitado pelo social, determinado pelas propriedades enraizadas em uma cultura; 2) abrir os campos da disciplina, a fim de tomar a arte também como objeto, tal qual vivido por seus atores (Heinich, 1998). A partir da interseção entre as duas esferas, adoto como critério diretor deste artigo a noção de hermenêutica, que compreende o ato da leitura, ou seja, o momento da troca da experiência estética e seu efeito sobre o destinatário. ${ }^{1}$ Considerando a natureza

\footnotetext{
* Doutora em Sociologia pela Universidade Federal do Rio de Janeiro. Pesquisadora do Núcleo de Pesquisa em Sociologia da Cultura (NUSC), IFCS/UFRJ.

Largo do São Francisco de Paula, 1, sala 109. Cep: 20051070 Centro Rio de Janeiro, RJ. eliskaaltmann@gmail.com

1 Tanto a "leitura" quanto a "interpretação" são aqui entendidas por denotarem uma inferência ao significado. Desse modo, contrariamente a David Bordwell (1995),
}

sígnica da obra de arte como essencialmente comunicativa, que pressupõe um receptor, o objeto da sociologia aqui aplicada está relacionado ao estudo das condições de recepção no âmbito do cinema. No caso, proponho uma análise da recepção cinematográfica circunscrita à crítica, em duas especificidades e contextos: a que defende o "cinema de autor”, instituído em meados da década de 1950 pela política dos autores, e a contemporânea, quando alguns críticos e pensadores sugerem o risco de extinção tanto da crítica quanto do próprio cinema. ${ }^{2}$ Desse modo, a idéia é discutir posições da crítica como instituição, e o pressuposto é

não reservo o termo "leitura" apenas aos textos literários. A literatura, assim como a pintura e o cinema, são estruturas narrativas que servem ao leitor ou espectador como objetos de leitura ou de interpretação. Partindo de alguns princípios de Wolfgang Iser (1996), ressalto que o problema do receptor das imagens audiovisuais concerne igualmente aos leitores de outros textos.

${ }^{2} \mathrm{O}$ presente artigo faz parte de uma pesquisa mais ampla sobre a crítica de cinema na América Latina. Além de pensadores como Terry Eagleton (1991), para quem a crítica atual perdeu sua relevância social, as ideias aqui discutidas estão baseadas e inspiradas em entrevistas realizadas com críticos mexicanos, argentinos, brasileiros e outros. Para citar alguns nomes: Carlos Bonfil (México), Nelson Carro (México), Silvia Schwarzböck (Argentina), entre outros. 
pensar o cinema mais através de seus contextos sociais de circulação e recepção do que a partir de análises internas e reflexões estritamente conceituais.

O pano de fundo da discussão é a ideia de curto-circuito cultural, cujo princípio fundamental, sugerido por Pierre Bourdieu (1987), envolve a pergunta: será que podemos ler o que quer que seja sem perguntarmos o que está sendo lido, ou melhor, sem perguntarmos sobre as condições sociais de tal leitura? $\mathrm{O}$ ato de interrogar sobre as condições da leitura conduz a outro questionamento: $\mathrm{o}$ das condições sociais de produção da obra. O processo de decifração de ambos os papéis gera ainda uma terceira questão, que se dirige às condições sociais de formação dos leitores-espectadores, qual seja, até que ponto elas afetam a leitura que estes fazem das obras ou dos documentos que utilizam. Assim, com base nos papéis do cineasta e da crítica cinematográfica, o circuito aqui proposto é aquele entre "um letrado (leitor) que lê um leitor (letrado)" (Bourdieu, 1987, p. 133). Tal esquema se dá na interseção de dois agentes: o cineasta, que a partir de sua recepção do "real" (ou de seu mundo vivido) cria imagens identitárias (que envolvem contextos nacionais), e o crítico, que recepciona tais imagens e delas recria novos imaginários acerca de significados sobre "realidade" e identidade.

\section{HOMOLOGIAS DA RECEPÇÃO}

Refletir o cinema por meio de suas práticas e condições de circulação requer um exame a respeito dos fundamentos de um trabalho sociológico no campo da arte. Os vínculos estabelecidos entre representações sociais e conhecimento científico implicam questões acerca de: (a) o que a arte representa; (b) como ela se relaciona com as transformações sociais; e (c) de que forma ela é recepcionada. Pensar o processo artístico de elaboração das condições sociais requer não apenas uma apreciação das linguagens artísticas, suas exigências, modos de produção e condições de apropriação, como uma análise que compreenda o artista, a obra, seu contexto social e seus receptores, uma vez que estes são elementos interdependentes. Nesse caso, é interessante enfatizar os efeitos sociais da arte cinematográfica, traçando linhas daquilo que se desenvolve sob o nome de sociologia da arte ou sociologia cultural. ${ }^{3} \mathrm{Tal}$ campo une as dimensões das ciências sociais e das manifestações culturais e artísticas, que representam os processos sociais de produção de obras, sua recepção, difusão e seus efeitos. Nesse processo, o cineasta deve ser entendido como aquele que estabelece uma reconstrução imaginária, que não é um reflexo direto da realidade, mas uma apreensão daquilo que a estrutura. É então, no nível das narrativas situadas na obra, que deve ser feita a análise dessa composição particular. O cinema passa a ser considerado como produto que se situa sobre o plano das atividades materiais e imaginárias de um grupo social dado.

Das relações entre arte e sociedade é válido atentar para aquilo que Lucien Goldmann (1964) designa por "homologias de estrutura". Elas indicam que a relação entre o pensamento coletivo e as criações individuais reside não numa identidade de conteúdo, mas em homologias de estruturas que podem se exprimir por conteúdos imaginários, diferentes do conteúdo real da consciência coletiva. A relação criada na e pela obra é aquela de elementos imaginários, cuja organização estrutural é gerada pelas representações coletivas. A estrutura da obra, nesse sentido, é quase necessariamente um produto da estrutura dessas representações. Tanto o determinismo que encerra a obra

\footnotetext{
A sociologia da arte busca se colocar em relação às obras e o meio em que são produzidas, a fim de estabelecer interpretações que permitem compreender o funcionamento da relação entre arte e sociedade. A descrição da sociologia da arte e da cultura pelos grandes temas implica, segundo Raymonde Moulin (1999), um enfoque a respeito de cada uma das artes consideradas. A unidade relativa do campo não significa que ele não tem uma especificidade aproximativa entre as pesquisas relativas a essa ou àquela prática artística. Os conteúdos da literatura e da música são abordados de maneira variada, assim como os problemas econômicos são distintos para o cinema, o teatro e a literatura. Assim, progressivamente, no lugar da expressão "sociologia da arte", tem-se preferido usar a expressão "sociologia das artes" de forma a mostrar a diversidade de domínios de pesquisa e a autonomia relativa das investigações sobre cada uma das artes. O uso dessa vertente sociológica no plural implica uma abrangência que também dá preferência ao termo "sociologia cultural".
} 
no artista quanto o que o reduz à estrutura social podem correr o risco de ser insuficientes para dar conta do processo de criação. Por esse motivo, é melhor pensar o cinema como reflexo da sociedade e provedor de suas novidades. Nesse sistema de significados, a arte cinematográfica é entendida por meio de suas raízes sociológicas, sendo, ao mesmo tempo, documento e técnica de análise para melhor conhecer o social. Por seu lado, a tarefa da sociologia é buscar o social na arte e encontrar nela o conhecimento do social. Tal homologia propõe um vai-e-vem das funções internas e externas da arte: o que pode ser estabelecido por sua análise interna encontra apoio em fatos externos de sua recepção; e, inversamente, aquilo que é remarcado em sua investigação externa encontra correspondentes em suas condições de produção.

Entre sociologia do produtor de arte e sociologia da fruição, é importante que seja feita uma distinção. Enquanto a primeira busca o processo de produção de novos valores sócioestéticos, a segunda visa a estabelecer as consequências dessa produção sobre os receptores e, consequentemente, sobre a própria sociedade. Sob essa perspectiva, o artista é visto, ao mesmo tempo, como dependente de sua sociedade e dela se emancipando. Isso quer dizer que, no lugar de considerar o social como uma realidade estática, ele deve ser tomado como algo dinâmico, onde o criador de arte é aquele que dela traduz seus reflexos e a ela oferece novas visões. Nesse sentido, as ferramentas trazidas pela sociologia da arte devem permitir compreender a experiência artística na experiência social. Tal concepção sociológica põe em relação as estruturas da obra com as estruturas do mundo. Isso quer dizer, por um lado, que, contrariamente a um sociologismo externalista, a análise dos efeitos ou dos contextos sociais da arte pode ser remetida à análise estrutural interna das obras, uma vez não sendo conduzida como análise de uma prática simbólica anonimizada. Por outro lado, contrariamente aos formalismos internalistas, a análise interna da literalidade ou da iconicidade representacional deve encontrar, na estrutura do texto ou do ícone, razões suficientes e questões pertinentes na análi- se externa do funcionamento das obras como algo culturalmente mais amplo. Desviando de correntes por vezes reducionistas da sociologia, que trabalham simetricamente com as operações de generalização e particularização, considero válida a adoção de uma postura a-crítica, que consiste não mais em validar ou invalidar aquelas ordens, mas em compreender como os atores as constroem, as justificam e as põem em prática em seus discursos e atos. Tal postura envolve a passagem de uma sociologia crítica para uma sociologia da crítica.

Dessa passagem, vale esclarecer desde já a posição aqui tomada. Considero toda obra cultural como resultado de experiências do mundo da vida, cabendo ao crítico a tarefa de elucidar estruturas ocultas sob as quais a obra se organiza, o terreno que as propicia e o conteúdo profundo daquilo que se imprime em sua forma. Essa concepção leva-me a questionar diferenciações entre manifestações artísticas de "arte pela arte" e "arte comercial", que servem aos mecanismos das distinções entre classes sociais e suas frações. Como será visto, o princípio metodológico que descarta mecanismos distintivos está afinado com o pensamento de um dos grandes representantes do estudo da recepção, Hans-Georg Gadamer (2005), para quem a realização da compreensão, ao abranger a experiência da obra de arte como um todo, supera qualquer historicismo no âmbito da experiência e (ou) da consciência estética. Essa última, por ser fechada em si, pensa a arte por intermédio da descontinuidade de vivências, consequência em desacordo com a concepção da hermenêutica, a postular que, nesse terreno, não existem limites estritos, e que o desfrute da compreensão não pode se deixar restringir ao mecanismo um tanto redutor da distinção estética. A rejeição a formulações distintivas gera a problematização de dualidades culturais como "alta" e "baixa", que podem dar sequência a outras oposições simetricamente polarizadas, gerando implicações pejorativas para a arte, tais como, "educada" versus "vulgar" e "pura" versus "impura".

Na medida em que o mundo está composto de obras de arte e, em cada uma delas, compõe- 
se um mundo, esse não é um universo estranho que nos projeta, momentaneamente, como um encantamento. Pelo contrário, nele aprendemos a conhecer a nós mesmos, e isso quer dizer que superamos, na continuidade de nosso estar no mundo, a descontinuidade e o pontualismo da vivência. Por isso, é importante "ganhar frente ao belo e à arte um ponto de vista que não pretenda a imediatismos, mas que responda à realidade histórica do homem” (Gadamer, 2005, p. 138). Com base nesse raciocínio, uma das consequências do estudo da recepção está no fato de que "todo encontro com a linguagem da arte é o encontro com um acontecer inconcluso e ao mesmo tempo parte desse acontecer” (2005, p. 141). Tal proposição segue a conjunção de duas dinâmicas: a da arte que se faz e a da sociedade que a transforma. Esse ponto compreende uma dialética que reflete o modo pelo qual a função da arte se transforma em um mundo em constante transformação. Nessa dialética está a própria razão de ser da arte: o fato de nunca permanecer inteiramente a mesma. Entretanto, a despeito de suas transformações, a arte, de alguma forma, expressa sentidos permanentes. Assim como a liberdade interpretativa depende da estrutura formal da obra, a obra pode prever seu leitor. Em síntese, esse entendimento gera a seguinte posição:

toda arte é condicionada pelo seu tempo e representa a humanidade em consonância com as ideias e aspirações, as necessidades e as esperanças de uma situação histórica particular. Mas, ao mesmo tempo, a arte supera essa limitação e, dentro do momento histórico, cria também um momento de humanidade que promete constância no desenvolvimento" (Fischer, 1966, p. 21).

Tal fundamento estrutura o pensamento em torno de duas propostas interdependentes: 1) é necessário buscar na obra aquilo que ela diz em referência à sua própria coerência contextual e à situação de sistemas de significação a que se refere; 2) é necessário buscar na obra aquilo que o destinatário encontra em referência aos seus próprios sistemas de significação e (ou) em referência aos seus próprios desejos e pulsões.

Através desse duplo movimento, cinema e crítica devem ser lidos por intermédio de um cará- ter social e comunicacional em um processo dinâmico e equivalente ao próprio processo cultural: aquele que abrange o circuito produção-circulaçãoconsumo (que envolve apropriação e ressignificação). O princípio do qual se deve partir é o de que uma obra de arte não chega a sê-lo se não é recebida (Canclini, 1980, p. 39). Mais ainda, a obra de arte só completaria sua função no circuito cultural quando, na recepção, forem incorporadas novas significações. A recepção, portanto, seria o recurso que encerra o acontecimento artístico e lhe faculta novos sentidos. Assim,

... se a recepção da obra completa sua existência e altera (de certa forma) sua significação, devese reconhecê-la como um momento constitutivo da obra, de sua produção, e não como um episódio final em que só se digeririam, mecanicamente, significados estabelecidos a priori e em forma definitiva pelo autor. Logo, é evidente que o juízo sobre a obra deve levar em conta tanto o processo de produção como o de sua percepção, ou seja, não apenas de que modo a obra se insere na história da produção artística ou renova os procedimentos de realização, mas também de que forma se insere na história do gosto, aceita ou modifica os códigos perceptivos vigentes (Canclini, 1980, p. 39).

Objeto da reflexão hermenêutica, o cinema participa de um duplo devir: o de si próprio, como obra, e o do sujeito que o lê. Ele não consiste em um objeto frente a um sujeito também imerso em si mesmo. Pelo contrário, ganha função no fato de se converter em uma experiência a modificar quem a experimenta. Dentro de uma universalidade do aspecto hermenêutico, a recepção deixa de ser um mero comportamento subjetivo em relação a um dado objeto para pertencer à história dos efeitos.

A crítica, sob esse aspecto, não participa de um "círculo metodológico", mas descreve um momento estrutural ontológico da compreensão. Ela está relacionada a uma espécie de antecipação de sentido, na medida em que, ao interpretar, o crítico deve, primeiramente, entender-se na coisa, e secundariamente destacar e racionalizar a própria opinião como tal. O caráter de pertencimento comporta uma distância histórica a abranger o sentido específico da própria situação histórica do intérprete. Tal distância, longe de ser superada, deve 
ser vista como possibilidade positiva e produtiva do ato de interpretar. Com o círculo da compreensão, que abrange a distância histórica, o fenômeno hermenêutico se encerra, ou melhor, encerra em si o caráter original da conversação: a estrutura de pergunta e resposta. Ao converte-se em objeto de interpretação, o cinema oferece uma pergunta a seu intérprete, razão pela qual a interpretação é referência constante ao que foi perguntado. A esse processo pode-se denominar "horizonte do perguntar" ou "horizonte hermenêutico". ${ }^{4}$

Desconsiderando uma suposta unicidade platônica da arte, o fenômeno hermenêutico é compreendido como parte do encontro entre espectador-crítico e obra, de forma que esse domínio seja iluminado a partir do modo de ser da última. Isso significa que a obra não é um objeto vazio, que se enche subjetivamente de significado a cada recepção. Ao estabelecer uma mediação das significações originais da obra com a vida dinâmica, a crítica cumpre uma "historicidade da compreensão", realizada em um círculo no qual a compreensão envolve a interpenetração do movimento original da obra e do movimento do intérprete. Tal concepção contradiz o entendimento de que a obra deve ser tomada como parâmetro de suas próprias interpretações. Interpretar uma obra é, portanto, admitir a existência de uma linguagem crítica que age e autoriza a comparação entre o texto, sua história e a nova interpretação. Essa ideia sustenta a

${ }^{4}$ Hans Jauss (1993), outro autor fundamental na discussão da recepção, estabelece a ideia de "contrato de leitura”. Para Jauss a busca por uma função social da arte é atingida a partir do pressuposto de que a história da obra não se constrói por si só, mas por meio de "horizontes de expectativa", responsáveis por seu processo evolutivo como conseqüência de uma troca, de uma relação entre mensagem e destinatário. O entendimento desse processo se desvia de um modelo linear, de forma que o encadeamento passe necessariamente por um diálogo entre obra e leitor, fazendo surgir desse encontro novas obras e novas concepções de arte. Segundo Jauss, esse diálogo possui uma dupla implicação estética e histórica, uma vez que não existe uma interpretação puramente única e subjetiva. Nesse pensamento, não existe um "em si” da obra; essa essência seria desconstruída pela posição do leitor, que é um intérprete pertencente a um mundo histórico e social. A reconstrucão do horizonte de expectativa se daria a partir de uma desconstrução do “espírito da época” e da visão platônica da obra, isto é, a partir da fusão dos horizontes original e atual. Assim, quando o leitor a lê, ele não mais a interpreta no sentido original de sua historicidade, fato que demonstra que a pergunta do leitor não é a mesma que a original do autor e que a recepção é produtiva e não passiva. seguinte tendência hermenêutica: o funcionamento de uma estrutura narrativa escrita, pictórica ou cinematográfica se explica levando em consideração, para além do momento generativo, o papel do destinatário em sua compreensão e atualização. Entende-se, no caso, que a hermenêutica e, consequentemente, a crítica, em sentido lato, se apropriam do princípio segundo o qual a obra se imbui de novas formas por meio de suas diversas interpretações, sem que seu modo de ser seja alterado. Esse princípio leva em conta a relação entre o efeito social da obra e o horizonte de expectativa de seus destinatários situados historicamente, sem negar, entretanto, que as interpretações do texto sejam proporcionais à natureza de sua intentio profunda.

Entre os horizontes de expectativa e a intentio da obra, ocorrem eventualmente desencontros que não devem ser vistos como desvios ou incompreensões dos receptores em relação a um suposto significado "verdadeiro" das obras. O efeito artístico não estaria circunscrito nem à essência da obra em si nem a uma disposição estável do que se chamou "natureza humana", mas a modos de relação dos homens com os bens culturais, cujas características variam de acordo com os contextos sociais, as disposições de produção e as classes sociais. Assim, a recepção cinematográfica pode ser percebida a partir de códigos sociais que regem sua circulação.

\section{O "EU” ARTíSTICO E A FORMAÇÃO DO AUTOR}

Ao olhar para sua historicidade, para sua "realidade", o cineasta exerce uma função de espectador. É como espectador do mundo que dá forma às suas percepções, criando sua obra como espectador ativo. Por sua vez, ao recepcionar a obra, o crítico, que nada tem de passivo, a recria. $\mathrm{Na}$ medida em que recria a obra, o espectador-crítico não deixa de estar fazendo arte. Isso quer dizer que, assim como o artista, ele é um criador. Podese entender, portanto, que o circuito a envolver quem observa e quem cria compreende a crítica. Tal prática não está apenas na leitura posterior e 
prolongada da obra, mas em sua própria construção, baseada na percepção crítica de fragmentos da realidade. Tanto crítica quanto obra não se constroem fechadas em si, mas se referem e fazem parte de um mundo, de uma cotidianidade. Com base em duas cotidianidades, discutirei algumas posições e proposições da crítica.

"Segundo a tradição, arte e habilidade de julgar a obra de um autor". "Arte ou faculdade de examinar e/ou julgar as obras do espírito, em particular as de caráter literário ou artístico". As definições do termo "crítica" provêm do latim criticus, do grego clássico kritikos ou krités, que significa apreciação ou arte de julgar. No campo cinematográfico, a crítica se legitimou amplamente na década de 1960, sob o paradigma da política dos autores, instituído alguns anos antes pela revista francesa Cahiers $d u$ Cinéma. A partir de movimentos como a Nouvelle Vague e o Neorrealismo, a crítica, antes meramente formal, passa a valorar a estética de um artista peculiar a partir de concepções políticas. Elaborada por um grupo de jovens críticos, a política dos autores surgiu com um artigo escrito por François Truffaut em 1954, intitulado Une certaine tendance du cinéma français, que não entra na categoria de "teoria do cinema”, apesar de ter se tornado referência. O trabalho do crítico, a partir de então, ganha o propósito de contribuir na formação de um espectador reflexivo, analítico e crítico, que deveria tomar uma atitude ativa frente ao que assistisse na tela, contando com novos e específicos conhecimentos para opinar sobre uma obra fílmica.

Sumariamente, a noção de auteur se remete à contribuição individual dada à obra cinematográfica, ao "si mesmo", à individuação pelo estilo proposta que contraria a idéia de cinema industrial, "massivo", de puro entretenimento. Essa concepção naturaliza uma diferenciação entre cinema industrial - imediatamente consumível - e cinema autoral, não industrial, feito com equipe mínima, de preferência "com uma câmera na mão e uma idéia na cabeça". ${ }^{5} \mathrm{~A}$ idéia de unicidade pro-

\footnotetext{
Em referência ao cineasta brasileiro Glauber Rocha, que, em seu livro Revisão crítica do cinema brasileiro, escreve: "na tentativa de situar o cinema brasileiro como expressão cultural, adotei o 'método do autor' para anali-
}

move uma diferenciação do sujeito a induzir à idéia de não-cotidianidade e, consequentemente, à arte não consumível e "reprodutível". Apesar do uso repetido, o termo autor no campo cinematográfico não foi, a princípio, de fácil definição. No início de seu livro, quando levanta a pergunta "o que é um autor?”, Jean-Claude Bernardet responde: “com certeza nada que possa ser definido de forma precisa, nem em geral nem nos quadros da política" (1994, p. 13). Apropriada pelo campo cinematográfico mais amplo, a idéia de cinema de autor refere-se a uma concepção antiindustrial, ${ }^{6}$ em que o cineasta, livre para criar sua própria narrativa, faz da câmera uma "caneta" e de seu nome uma assinatura. Nesse sentido, o autor está se referindo à idéia de escritura cinematográfica, cuja expressão máxima é a de quem assina.

Com base no método autoral, a experiência que molda a ideia do autor cinematográfico é a do escritor e seu livro ${ }^{7}$ (Bernardet, 1994, p. 15). Podese dizer, portanto, que a noção de autor derivaria precisamente da crítica literária. Contra a idéia de criação coletiva, os críticos dos Cahiers du Cinéma buscaram alinhar o cinema à literatura e alcançar seu processo de legitimação intelectual a uma alta camada do campo cultural.

Muitas vezes considerado como um modo de reflexão sobre o real, o cinema, quando realizado pela unidade sujeito-autor, ressoa seu poder

sar sua história e suas contradições; o cinema, em qualquer momento da sua história universal, só é maior na medida dos seus autores. [...] A política de um autor moderno é uma política revolucionária: nos tempos de hoje nem é mesmo necessário adjetivar um autor como revolucionário, porque a condição de um autor é um substantivo totalizante" (Rocha, 2003, p.36).

${ }^{6}$ É válido notar que a apropriação desse método no país ganhou uma tônica diferente da dos críticos franceses, cuja concepção englobava uma reconsideração da produção hollywoodiana, por intermédio da canonização de cineastas como Alfred Hitchcock, Howard Hawkes e John Ford. De modo inverso, a produção autoral brasileira era aquela que assumia compromisso com a intervenção política na realidade social, se opondo, portanto, à indústria - diretamente ligada a uma concepção colonizadora. Nesse sentido, sugere-se que a apropriação da concepção autoral no Brasil (e na América Latina) está relacionada à elaboração de uma identidade no cinema.

${ }^{7}$ Ainda de acordo com Bernardet, "os escritores são considerados como valores seguros no firmamento da cultura, de forma que reencontrar aspectos de seus temas em filmes é maneira de valorizá-los e de consolidar o status do cineasta. [...] Há uma nobreza literária que contamina o cinema" (1994, p. 16-17) 
de exprimir problemas histórico-sociais, conferindo ao artista a função de porta-voz de sua coletividade. Esse entendimento indica que, para que o cinema seja de autor, é necessário que ele seja mais do que um registro "objetivo" do real. É necessário que, como arte, ele proponha um olhar personalizado do mundo, uma forma de pensar própria do artista, inteiramente responsável por sua obra. Énecessário que, como arte, o cinema seja um meio de expressão de alguém. Quando meramente "efeito do real", não é necessário que um autor aperte o botão da câmera, pois qualquer profissional pode fazê-lo (Bernardet, 1994). O importante a se notar, nessa concepção, é que, por detrás da função do cineasta, está o próprio ego do autor - fato que contem uma contradição, pois, ao mesmo tempo em que nega uma arte massiva e coletiva, o autor parece portador de sua própria negação: usa seu próprio nome para falar em nome da coletividade ou popularidade, sem ser efetivamente popular.

Considerando que o autor se institui como um sujeito que se expressa a partir de regularidades, e a política, como o método que qualifica o autor dentro de uma coerência de sua expressão subjetiva, entende-se que o crítico alça à categoria de autor aquele que compreende uma obra a partir de similitudes temáticas. Ao interpretar a obra do autor como um sistema de repetições, a crítica fundamenta a política não a partir de um filme isolado, mas de um "fazer parte" de um conjunto de narrativas específico. Com base nesse método "quase religioso", críticos, cineastas e cinéfilos passaram a se distinguir, na medida em que "o autor, em última instância, revela Deus, e não será essa a função do cinema?" (Bernardet, 1994, p. 65). Assim, a autoria passa a permitir que a cinefilia e, por extensão, a crítica se convertam socialmente em uma forma de distinção, pois se trata não apenas de uma concepção do cinema, mas também do gosto. Digo crítica como extensão da cinefilia em razão de a primeira não ser composta na época por um campo "profissionalizante". Na falta de "formação" para tornar-se crítico, havia duas condições primordiais para sê-lo: a devoção ao cinema e a vocação para sua escritura. Nesse campo, não é incomum o cinéfilo, além de ser crítico, ser também cineasta. Desse aspecto, vale ressaltar que o processo de legitimação do termo autor é orquestrado por diversas frentes, mas, principalmente, pela cinefilia. O surgimento dos cineclubes, como espaços alternativos de discussão, onde eram exibidos filmes não comerciais, foi de fundamental importância no processo de inserção do cinema de autor como meio legítimo de expressão.

\section{CIRCUITOS DA CRÍTICA}

Autor-crítico, cinéfilo-crítico, cinéfilo-autorcrítico, esse híbrido configurava o campo cinematográfico nos anos 1960. Para o crítico brasileiro José Carlos Avellar, "esse foi um período privilegiado da crítica, talvez porque os realizadores, agindo como críticos, convidavam os críticos a se comportarem como realizadores, e os espectadores, como realizadores e críticos simultaneamente" (1996, p. 42-46). Devido a essa espécie de mistura não-sistematizada do campo, um dos estatutos da crítica consistia em abordar seu objeto - o filme sem respaldo teórico aprofundado. Os ensaios eram escritos mais por inspiração no próprio filme e nas discussões sobre as impressões sentidas pelos cinéfilos em seus espaços apropriados (especialmente os cineclubes) e menos baseados em teorias sobre "postulados da crítica", ou análises cinematográficas. Sendo assim, poder-se-ia dizer que o ensaio crítico consistia em uma teorização livre, tomada, por sua vez, como um fluxo de pensamento operado, cujo único método pré-estabelecido era o do autor. Amplamente baseada na autoria - ou na política dos autores, que não deve ser confundida com "teoria de autor" -, a crítica acabava por não incorporar plenamente análises derivadas da linguística, como a semiótica e as análises do discurso. Da mesma forma que a crítica literária ou a filosófica não produzem literatura ou filosofia, a crítica de cinema tampouco produziria teoria cinematográfica (Schwarzböch, 2000).

Da geração de cineastas-autores, como Glauber Rocha, Avellar parece corroborar esse prin- 
cípio de formação, ao sustentar que

muitos de nós começaram a exercer a crítica num momento em que a produção cinematográfica exigia um comportamento crítico do espectador. A discussão dos critérios de avaliação do cinema decorria mais da produção cinematográfica do que da reflexão cinematográfica. Entre a metade da década de 50 e de 60, a reflexão ficou muito mais na prática do que na teoria (1985, p. 5).

Dessa configuração, entende-se que o exercício crítico era mais “intuitivo” do que puramente "profissional". Essa espécie de "subordinação sensível” ao filme fez com que a crítica de cinema se diferenciasse da teoria cinematográfica, gerando uma espécie de teorização com ausência de método. A possibilidade de escrever sem teorias de respaldo pode ser vista como uma vantagem e não uma deficiência, pois a ausência de método teria aberto um espaço inédito para a reflexão que não se restringia ao crítico, mas se estendia e formava o próprio espectador. Como observa Avellar,

... a crítica era feita não só por profissionais, que escreviam com regularidade em jornais e revistas, como também pelo espectador. De certo modo, desenvolvemos na América Latina uma espécie de crítica de espectador, aquele que conseguia ver mais filmes e organizava qualquer forma de registro, arquivo ou fichário. Ler a crítica era parte do ritual cinematográfico. Os anos 60 foram o momento em que os filmes eram reflexão e reflexo, debate direto e vivo da realidade e vontade de nos definirmos diante dela (Avellar, 1996, p. 42).

O espectador que lê o crítico que é cinéfilo e que também faz cinema, eis o circuito crítico cuja hermenêutica aqui interessa. Nesse circuito, a crítica cinematográfica pode ser entendida como a instância que participa ativamente da formação e consolidação de interesses, preferências, conhecimentos e emoções do público que se relaciona com a obra. Ela, então, se torna instrumento reflexivo a dialogar com a sensibilidade do espectador "COmum”, face aos problemas da arte e do mundo em que vive. Considerando o cinema como uma forma complexa que se vale de uma linguagem própria, possuindo técnicas e leis particulares, a crítica deveria aportar conhecimentos necessários para a compreensão da obra, trazendo informações e esclarecendo possibilidades de recepção do que é representado na tela. No âmbito da política de autor, creio que uma importante questão a ser levantada sobre o papel da crítica é a seguinte: será que ela privilegia um leitor ideal?

Na década de 1960, a crítica que instituiu o conceito de autor, denominada por muitos de "ilustrada" ${ }^{8}$ era difundida principalmente em revistas e meios especializados, de circulação restrita. A consciência de pertencer a um grupo social valorizado se apoiava na ideia de estar a serviço de um projeto criador. Os participantes desse projeto eram detentores de um habitus qualificado, produtor de uma ideologia específica. Assim, o controle e a articulação dos agentes garantiam regras e práticas que se legitimavam pela ideia do "dever" dar suporte a um autor ou uma cinematografia específicos. Essa ideia e as políticas inspiradas por ela asseguravam um campo e conferiam seu prestígio. Contudo, a partir do momento em que esse campo sofre transformações, o status do crítico, como parte de um grupo qualificado, passa a ocupar um espaço indeterminado a meio caminho entre uma ilustração atuante e uma "contraesfera pública desejável, mas inexistente” (Eagleton, 1991, p. 104).

O cineclubismo e a cinefilia sofreram transformações significativas da década de 1960 para os dias de hoje. Não obstante a produção especializada e restrita, a crítica cinematográfica experimenta um processo de democratização, ampliada com o advento de novos espaços, como os meios eletrônicos, por exemplo. Em grande parte devido a essa democratização, vista por alguns como de "baixa" qualidade, parte da crítica crê no ocaso de sua função. A escassez de meios especializados em favor de uma proliferação de espaços (em sua maioria, virtuais) suscita, em certos críticos, a constatação do ocaso de seu campo. Uma das hipóteses sustentada é a de que os suplementos e espaços culturais, antes dedicados à "arte”, deram lugar a generalizações ou espetáculos. Tal consenso se baseia no fato de que a cultura cinefílica ilustrada tornou-se “profissionalizada”, não mais dependendo de uma devoção ou intelectualização da

${ }^{8}$ Para mais detalhes, ver Schwarzböck (2000). 
arte cinematográfica, mas de um conhecimento superficializado, unido a uma burocratização escritural. Outra hipótese é a de que um suposto fim da crítica estaria diretamente relacionado ao "ocaso" do próprio cinema. Nesse caso, como contextualizar certas tendências do cinema atual e sua recepção? Que cinema é esse que está em vias de desaparecimento para a crítica? Pensar essas questões no âmbito sociológico requer o cuidado na consideração de certas reduções deterministas, pois, se o cinema e a crítica estivessem em vias de extinção, a própria sociologia da arte e da recepção correria o mesmo risco. Extinguindo-se o cinema e sua crítica, consequentemente se extinguiria sua sociologia. Vejamos, entretanto, se a problemática é tão pessimista quanto parece.

Tomando o cinema brasileiro como exemplo, a distinção entre o Cinema Novo, de autor, e o "novo cinema", contemporâneo, é vista por críticos como Carlos Alberto Mattos (1998) no sentido de que o "cinema da retomada" não surgiu de um projeto estético-político como o primeiro. Nesse sentido, o cinema contemporâneo teria surgido sem manifesto, sem programa de ação nem qualquer característica coletiva de movimento. Pelo contrário, nascera da justaposição de individualidades, cada uma com seu projeto particular, cada qual com sua ideia de cinema na cabeça - uma ideia que, para muitos, não soa como uma ideia de cinema brasileiro, mas de cinema de qualquer lugar, estrangeiro por definição na sua recusa de carregar a pesada bandeira da identidade nacional. Estaria esse pensamento sugerindo uma inviabilidade de "autores" preocupados com representações identitárias em nossos dias? Tal inviabilidade ocasionaria a inviabilidade do cinema e da própria crítica?

A concepção de cunho sociopolítico proposta por cinemanovistas como Glauber Rocha, por exemplo, contrária a uma perda internacionalizada de vínculos, orientava-se em direção a uma congruência de fatores eminentemente nacionais por intermédio da fusão dos diversos movimentos na época que, valorizando as culturas populares originais, formaram uma inter-relação estética e ideológica. Tomando outra direção, a recepção crítica nacional em torno do cinema contemporâneo suscita a idéia de que ele esboça uma estética "internacional popular", ${ }^{9}$ situada entre uma "internacionalização estética”, como parte de um estilo "global", esteticamente consumível e pasteurizado, e uma espécie de "popular internacionalizado" que, apesar de imprimir uma marca de origem, inclusive estética, é capaz de ser "legível” e atingir contextos para além do nacional.

O que parece relevante na discussão sobre os termos "nacional-popular" (culto e que permanece) e "internacional-popular" (inculto e pasteurizado) no âmbito do cinema e da crítica atuais é a condição do adjetivo que compõe ambos os estilos, o popular, ${ }^{10}$ especialmente por sua vinculação à noção de identidade. Aparentemente, a suposta transferência do gosto erudito para o fácil, vinculada ao suposto ocaso tanto do cinema quanto da crítica, estaria pautada nesse conceito, ou melhor, em sua transformação. A ideia é a de que o cinema culto anterior, apoiado na cultura popular, dá lugar a um cinema popular, em sentido massivo. Da mesma forma, a crítica, anteriormente culta e restrita, quando devotada ao autor do cinema nacional-popular, ganha amplitude massiva, atingindo veículos e públicos mais abrangentes.

O persistente debate que opõe o cinema (requintado) de arte ou de autor ao (fácil) industrial e massivo parece tão antigo quanto o próprio cinema e acaba por reduzi-lo à mera oposição "arte versus indústria”. Tal oposição é ainda hoje um argumento medular no campo da crítica latino-americana, sendo sustentada, em grande parte, por argumentos da Teoria Crítica, segundo os quais algo não pode ser considerado arte se for um produto da indústria. Parece-me necessário desconstruir tal ideologia. Vale lembrar que, já nos anos 1960, vozes questionadoras desses paradigmas passaram a

9 Trabalhado por Renato Ortiz e discutido por Ivana Bentes, tal termo, no âmbito do cinema, indica filmes com temas e tramas tipicamente nacionais, que optaram por um tipo de narrativa institucional, baseada no modelo clássico norte-americano. Para mais detalhes, ver Xavier (1998, p. 105-106).

${ }^{10}$ Não são poucos os debates sobre esse termo nos estudos do campo cinematográfico. Para maiores detalhes, destaco importantes fontes tais como: Galvão e Bernardet (1983) entre outros. 
valorizar justamente a ampla mediação do público, vista pelos frankfurtianos de forma amorfa e passiva. Contribuições valiosas como a de Edgar Morin (1977), que analisou diretamente o caso do cinema, revelam que a criação artística é plenamente compatível com a divisão do trabalho, com a mediação tecnológica e a estandardização.

A complexificação do pensar cinematográfico e artístico implica um deslocamento de sua recepção e, por conseguinte, também de sua sociologia. A estrutura dualista do campo cinematográfico, que opõe cinema de autor a cinema popular e massivo, devido à sua ampla utilização, é muitas vezes investida de um forte poder de sugestão. Entretanto, tal oposição pode complexificarse, quando, por exemplo, um filme de autor conquista um grande sucesso comercial, e quando um filme comercial é alçado à categoria de arte, ou mesmo quando um filme pretensamente comercial atinge um público inexpressivo, mas relevante. Desse modo, faz-se necessária uma problematização das noções de cultura alta e baixa, popular e massiva. O culto tradicional, por exemplo, não é necessariamente apagado pela industrialização dos bens simbólicos. No caso do popular, é necessário que se atente mais às suas transformações, ao invés de simplesmente postular sua extinção. A complexificação social proposta pela modernização não suprime o papel do culto e do popular tradicionais, mas recoloca a arte e o folclore, o saber acadêmico e a cultura industrializada em condições relativamente semelhantes (Canclini, 2005). Nesse sentido, é necessário que os pensadores e "fazedores" de cinema e arte rompam com certos maniqueísmos, relocalizando e redescobrindo o popular (assim como o culto, o massivo e outras categorias). ${ }^{11} \mathrm{Na}$ direção de tais deslocamentos teóricos e metodológicos, começa a se produzir "um

${ }^{11}$ Como sugere Jesús Martín-Barbero, “dizer 'cultura de massa', em geral, equivale a nomear aquilo que é entendido como um conjunto de meios massivos de comunicação. A perspectiva histórica que estamos esboçando aqui rompe com essa concepção e mostra que o que se passa na cultura quando as massas emergem não é pensável a não ser em sua articulação com as readaptações da hegemonia, que, desde o século XIX, fazem da cultura um espaço estratégico para a reconciliação das classes e a reabsorção das diferenças sociais. As invenções descentramento do conceito mesmo de cultura, tanto em seu eixo e universo semântico como no pragmático, e um redesenho global das relações entre cultura/povo, povo/classes sociais" (MartínBarbero, 2003, p. 102).

As relações estabelecidas no consumo de bens culturais promovem todo um sistema social de disposições. O sistema que aqui interessa é aquele que ainda parece envolver filmes "extraordinários”, críticos e leitores especializados - todos em vias de "desaparecer" - e que, juntos, formam uma "classe objetiva". Como sugerido por Bourdieu, a classe objetiva forma-se a partir de agentes que incorporaram habitus específicos e condições homogêneas de existência, que especificam condicionantes e gostos geradores de características distintivas, formadores de um estilo de vida particular. A relação entre classe objetiva e habitus promove o processo ideológico de distribuição de capital simbólico. Este compartilha um conjunto de condicionamentos e disposições homogêneas definidoras da utilidade de um produto, que não é nem objetiva nem independente das práticas sociais. Sob essa perspectiva, busco entender a sugestão de certos críticos em relação ao possível ocaso de sua função. Tal percepção parece ser consequência de uma "nostalgia" de filmes "extraordinários" e da desqualificação de filmes que não mais se constituem em torno de uma “aura” estético-política e autoral - constatação que leva a considerações como as que enquadram o Cinema Novo nos parâmetros da estética e o "cinema da retomada" em padrões "cosméticos". ${ }^{12}$ Essa lógica sugere a inviabilidade determinista des-

tecnológicas acham aí sua forma: o sentido que vai tomar sua mediação, a mutação da materialidade técnica em potencialidade socialmente comunicativa [... Estamos situando os meios no âmbito das mediações, (2003, p. 203).

${ }^{12}$ Em referência à expressão "cosmética da fome”, cunhada pela comunicóloga e crítica de cinema Ivana Bentes, no início dos anos 2000, que sugere uma "glamourização da pobreza". Em contraste com a "estética da fome", de Glauber Rocha, Bentes constata que a produção nacional contemporânea compreende "um cinema 'internacionalpopular' ou 'globalizado' cuja fórmula seria um tema local, histórico ou tradicional e uma estética 'internacional'. O sertão torna-se então palco ou museu a ser 'resgatado' na linha de um cinema histórico-espetacular ou 'folclore-mundo' pronto para ser consumido por qualquer audiência” (Bentes, 2007, p. 242-255 - grifo nosso). 
se último em atingir o status de "extraordinário".

Problematizar esse determinismo a partir da hipótese bourdieusiana da distinção pode ser bom método para se reconsiderar e re-localizar as estruturas até então estruturadas. Se considerarmos que não há gosto soberano nem gosto criado pelo sistema de produção, mas uma homologia entre bens ofertados e o campo de produção, chegaremos à conclusão do caráter não-inato de estruturas como as que determinam o popular (cinemanovista, autoral) e o massivo (onde se enquadra certo cinema contemporâneo).

Não devemos, contudo, nos esquecer da outra fração de agentes críticos que não compartilha desse sentimento nostálgico, percebendo positivamente a disseminação ou democratização tanto da crítica quanto do cinema, questionando termos distintivos-hierarquizadores. Ao examinar o campo da crítica contemporânea, o crítico de arte Luiz Camillo Osório verifica "um misto de arrogância e defesa de território embutido nessa nostalgia que insiste no fim da crítica" (2005, p. 9). Assim, a crise da crítica faz eco à crise da política, de um espaço comum, múltiplo e pautado pelas diferenças. Diversificar a crítica, incentivar a disseminação de seus sentidos e ampliar suas articulações e espaços são ideias que sugerem um bom início para pensarmos não apenas as novas condições de recepção como as relocalizações de conceitos aplicados de forma determinista e estática. A ampliação dos horizontes de recepção pode oferecer ao eixo do debate novos entendimentos como, por exemplo, o de que "se as reivindicações sociais e políticas das classes subalternas fizeram-se ouvir no conjunto nacional por intermédio do nacionalpopular, é num discurso de massa que o nacionalpopular se faz reconhecível pelas maiorias." (Martín-Barbero, 2003, p. 270).

Nesse sentido, entre a tendência autoral da crítica, que confere certa raridade ao cinema, e a crítica enquadrada em um suposto "gosto vulgar", há de se considerar suas relocalizações conceituais e receptivas. Debater reposições que dependem das reconfigurações tanto do campo cinematográfico quanto do público pode ser um bom caminho para pensar sociologicamente a crítica, veículo e funda- mento de tantas discussões das imagens do Brasil.

(Recebido para publicação em janeiro de 2008) (Aceito em setembro de 2008)

\section{REFERÊNCIAS}

AVELLAR, J.C. Arte da crítica, crítica da arte. Nossa América: revista do Memorial da América Latina, São Paulo, n. 1, p. 42-46, 1996.

BARBERO, J. M. Dos meios às mediações. Rio de Janeiro: Ed.a UFRJ, 2003. 372p.

BENTES, I. Sertões e favelas no cinema brasileiro contemporâneo: estética e cosmética da fome. Alceu: revista de comunicação, cultura e política, Rio de Janeiro, PUCRio de Janeiro- v. 8, n. 15, p. 242-255, jul./dez., 2007.

BERNARDET, J.C.; GALVÃO, M. R. O nacional e o popular na cultura brasileira - cinema. São Paulo: Secretaria da Cultura/MEC, 1983.

. O autor no cinema: a política dos autores - França, Brasil anos 50 e 60. São Paulo: Brasiliense: Edusp, 1994. 204p.

BORDWELL, D. El significado del filme. México: Ediciones Paidós, 1995. 347p.

BOURDIEU, P. Lecture, lecteurs, lettrés, literature. In: 132-143. Choses dites. Paris: Editions de Minuit, 1987. p.

CANCLINI, N. G. Culturas híbridas: estrategias para entrar y salir de la modernidad. Buenos Aires: Paidós, 2005. 352p. . A socialização da arte: teoria e prática na América Latina. São Paulo: Cultrix, 1980. 220p.

EAGLEON, T. A função da crítica. São Paulo: Martins Fontes, 1991. 122p.

FISCHER, E. A função da arte. In: VELHO, G. (Org.) Sociologia da arte. Rio de Janeiro: Zahar Editores, 1966. p. 15-23.

GADAMER, H.-G. Verdad y método I. Salamanca: Sigueme, 2005. 697p.

GOLDMAN, L. Pour une sociologie du roman. Paris: Gallimard, 1964. 240p.

HEINICH, N. Ce que l'art fait à la sociologie. Paris: Les Éditions de Minuit, 1998. 90p.

ISER, W. $O$ ato da leitura: uma teoria do efeito estético. São Paulo: Ed. 34, 1996. 192p. v. 1

JAUSS, H. R. A história da literatura como provocação à teoria literária. São Paulo: Ática, 1994. 79p.

MATTOS, C. A. Sinais de vida. Cinemais. Rio de Janeiro, n. 11 , p. 47-55, mai./jun. 1998.

MORIN, Edgar. O espírito do tempo II: necrose. Rio de Janeiro: Forense Universitária, 1977. 206 p.

MOULIN, R. Sociologie de l'art. Paris: L’Harmattan, 1999. 460p. OSÓRIO, L. C. Razões da crítica. Rio de Janeiro: Jorge Zahar Editor, 2005. 70p.

ROCHA, G. Revisão crítica do cinema brasileiro. São Paulo: Cosac \& Naif, 2003. 240p.

SCHWARZBOK, S. Diez tesis sobre la crítica de cine. El amant-Cine. Buenos Aires, n. 94, enero, 2000.

XAVIER, I. Inventar narrativas contemporâneas. Cinemais, Rio de Janeiro, n. 11, p. 79-120, maio/jun., 1998. 


\section{GLANCES OF THE RECEPTION, THE CINEMATOGRAPHIC CRITIC IN TWO TIMES}

\section{Eliska Altmann}

Based in propositions of the theory of reception, in the field of sociology of the culture, this paper discusses the role of the cinematographic review starting from two positions: the one that defends 'author's movies' and the one that assumes a supposed end of the critical function. The persistent debate opposing art or author's movies ('refined') to ('easy') industrial and massive ones seems as old as movies themselves and reduces movies to the mere opposition of 'art versus industry'. That seems still today as an fulcral argument in the field of criticism. The complexification of cinematographic and artistic thought implies in a displacement of its reception and, consequently, of its sociology. In that sense, one intends to debate the possible relocalizations of concepts, such as the ones that reduce movies to high' versus 'low' and 'educated' versus 'vulgar'.

KEYWORDS: cinematographic critic, sociology of the culture, reception theory.

\section{LES REGARDS DE LA RECEPTION, LA CRITIQUE CINÉMATOGRAPHIQUE EN DEUX TEMPS}

\author{
Eliska Altmann
}

Sur base de propositions de la théorie de la réception, dans le champ de la sociologie de la culture, l'article discute le rôle de la critique cinématographique à partir de deux positions: celle qui défend le "cinéma d'auteur" et celle qui croit en la "fin" de la fonction critique. La dispute persistante qui oppose le cinéma (sophistiqué) de l'art ou de l'auteur à un industriel (facile) semble si ancien tant que le cinéma lui-même est réduit à la pure opposition "l'art contre l'industrie". Celui-ci semble encore aujourd'hui un argument définitive dans le domaine de la critique. La complexité de la penseé cinématographique et artistique implique elle-même une dislocation de sa réception et, par conséquent, de sa sociologie. L'article se prétend, donc, a élargir le débat, en re-localisant des concepts comme ces qui entourent la culture sur la distinction "culture populaire" versus "culture de l'élite".

MотS-CLÉs: critique cinématographique, sociologie de la culture, théorie de la réception.

Eliska Altmann - Doutora em Sociologia pela Universidade Federal do Rio de Janeiro, com período sanduíche na Universidad Autónoma Metropolitana (UAM). Mestre em comunicação pela Escola de Comunicação da UFRJ e Bacharel em Ciências Sociais pela UFRJ. Desenvolve pesquisa sobre a recepção do cinema brasileiro pela crítica latino-americana. Foi professora substituta do Departamento de Comunicação da Universidade Estadual do Rio de Janeiro (UERJ). É professora do Departamento de Cinema da Universidade Estácio de Sá. A autora tem se dedicado à Sociologia da Cultura, realizando estudos e apresentando trabalhos em eventos nos seguintes temas: cinema, movimentos culturais, crítica cinematográfica e recepção de bens culturais. Atualmente realiza pesquisa junto ao NUSC - Núcleo de Pesquisa em Sociologia da Cultura, da UFRJ. 